\title{
Influence of humic fertilizers on growth and biochemical parameters of lettuce plants
}

\author{
(C) Svetlana G. Skugoreva, ${ }^{1}{ }^{+}$Tamara Ya. Ashikhmina, ${ }^{1,2}$ \\ Grigory Ya. Kantor, ${ }^{1,2}$ and Nadezhda V. Syrchina ${ }^{1}$ \\ ${ }^{1}$ Biomonitoring Laboratory. Institute of Biology of the Komi Scientific Center. Ural Branch of the Russian \\ Academy of Sciences. Kommunisticheskaya St., 28. Syktyvkar, 167982. Komi Republic. Russia. \\ Phone: +7 (8332) 37-02-77. E-mail: skugoreva@mail.ru \\ ${ }^{2}$ Institute of Chemistry and Ecology. Vyatka State University. Moskovskaya St., 36. Kirov, 610000. \\ Kirov Region. Russia.Phone: +7 (8332)35-64-65.E-mail: usr08615@vyuatsy.ru
}

\begin{abstract}
*Supervising author; ${ }^{+}$Corresponding author
\end{abstract}
Keywords: humic substances, humic fertilizers, lettuce plants, chlorophyll $a$, chlorophyll $b$, carotenoids, biomass, lipid peroxidation.

\section{Abstract}

Humic fertilizers (HF) are a separate group of organic fertilizers, which include humic acids (HA), fulvic acids (FA), their salts, as well as some mineral componenrs. They combine the beneficial properties of macro- and microelements, adaptogens, biofungicides, plant growth stimulants. The aim was to study the effect of the introduction of a humic preparation obtained from peat into the soil and fertilizers "Sotka Potassium Humate" (Sotka) on the growth and biochemical parameters of lettuce plants. In the course of the work, a humic preparation was obtained from milled peat of the production site "Gorokhovsky" (Kotelnichsky district of the Kirov region) of the branch of VyatkaTorf JSC by the method of leaching of humic substances (HS). The HS content in the obtained preparation was $23.4 \%$ (18.6\% HA and 4.8\% FA). It was found that the humic preparation from peat had a greater effect on the accumulation of pigments by plants than the Sotka HF. The effect was especially pronounced with a single application of the drug to the soil; over time, this effect decreased. The effect of using Sotka fertilizer was manifested when it was applied as a top dressing on the 30th day after planting the seeds. Based on the results of the study, a series of photosynthetic pigments in descending order of HFs effect on their accumulation has been constructed: chlorophyll $a>$ chlorophyll $b>$ carotenoids. Along with the accumulation of pigments, the introduction of HF into the soil led to an increase in growth parameters and lipid peroxidation in lettuce leaves, which indicates a greater intensity of biochemical processes occurring in plants under the influence of HS.

\section{References}

[1] I.V. Perminova. Humic substances - a challenge to chemists of the XXI century. Chemistry and Life. 2008. No.1 [Electronic resource] https://elementy.ru/nauchno-populyarnaya_biblioteka/430559 (Date of access: 16.12.2020).

[2] A.I. Popov. Humic substances: properties, structure, education. Ed. E.I. Ermakova. St.Petersburg: Publishing house of St. Petersburg. un-that. 2004. 248p. (russian)

[3] D.S. Orlov. Humic substances in the biosphere. Soros Educational Journal. 1997. No.2. P.56-63. (russian)

[4] B.V. Levin, S.A. Ozerov, G.A. Garmash, N.V. Latina, N.Yu. Garmash. Increasing the agrochemical efficiency of complex phosphorus-containing fertilizers due to the humate additive. Plant nutrition. 2015. No.2. P.2-7. (russian)

[5] O.A. Makarov, A.A. Stepanov, N.F. Cherkashina, O.A. Chistova, N.N. Panina. Experience in assessing the effect of humic preparations on the yield and quality of potatoes. Agrochemical Bulletin. 2016. No.1. P.22-26. (russian)

[6] A. Piccolo, G. Celano, G. Pietramellara. Effects of fractions of coal-derived humic substances on seed germination and growth of seedlings (Lactuga sativa and Lycopersicum esculentum). Biology and Fertility of Soils. 1993. Vol.16. P.11-15. doi: 10.1007/bf00336508

[7] A.D. Noble, P.J. Randall., T.R. James. Evaluation of two coal derived organic products in ameliorating surface and subsurface soil acidity. Europ. J. Soil Sci. 1995. Vol.46. P.65-75. doi: 10.1111/j.13652389.1995.tb01813.x 
INFLUENCE OF HUMIC FERTILIZERS ON GROWTH AND BIOCHEMICAL PARAMETERS...

[8] D. Vaughan, J.R. McDonald. Effects of humic acid on protein synthesis and ion uptake in beet discs. $J$. Exp. Bot. 1971. Vol.22. P.400-410.

[9] E. Sebestova, V. Machovic, H. Pavlikova. Structural characterization and heavy metal sorption properties of coal derived humates. The role of humic substances in ecosystems and in environmental protection / Eds. J. Drozd, S.S. Gonet, N. Senesi, J. Weber. PTSH, Wroclaw, Poland. 1997. P.199-206.

[10] I.A. Potapova, E.V. Burova, P.P. Purygin, and Yu.P. Zarubin. The preparation of hydrazide humic acids and the study of their complexation with copper(II) ions. Butlerov Communications. 2017. Vol.52. No.10. P.88-97. DOI: 10.37952/ROI-jbc-01/17-52-10-88

[11] G.Ya. Kantor, S.G. Skugoreva, L.I. Domracheva. Comparative analysis of the kinetics of sorption of lead(II) ions by various sorbents. Ecology of the native land: problems and solutions: Materials of the XIII All-Russian scientific-practical conference with international participation. Kirov: Vyatka State University, 2018. P.96-100. (russian)

[12] S.S. Dragunov. Chemical characteristics of humic acids and their physiological activity. Humic fertilizers, theory and practice of their application. Kiev: Urozhay. 1980. Vol.VII. P.5-21.

[13] Photosynthetic pigments - chemical structure, biological function and ecology / Eds. T.K. Golovko, W.I. Gruszecki, M.N.V. Prasad, K.J. Strzalka. Syktyvkar: Komi Scientific Centre of the Ural Branch of the Russian Academy of Sciences. 2014. 440p.

[14] A.S. Lukatkin, V.S. Golovanova. Intensity of lipid peroxidation in chilled leaves of heat-loving plants. Plant physiology. 1988. Vol.35. No.4. P.773-780. (russian)

[15] O.S. Bezuglova, E.A. Polienko, A.V. Gorovtsov. Humic preparations as stimulators of plant and microorganism growth (review). Agronomy and forestry. 2016. No.4(60). P.11-14. (russian)

[16] VyatkaTorf [Electronic resource] http:/www.vyatkatorf.ru/about.html (Date of access: 16.12.2020).

[17] D.S. Orlov, L.A. Grishina. Workshop on the chemistry of humus. Moscow: Publishing house of Moscow State University. 1981. 272p. (russian)

[18] A.E. Russkikh, S.G. Skugoreva. Obtaining a preparation containing humic substances from peat. Utilization of production and consumption waste: innovative approaches and technologies: Materials of the All-Russian scientific and practical conference with international participation. Book. 1. Kirov: VyatSU. 2019. P.220-223. (russian)

[19] A.P. Kudryashov, T.I. Ditchenko, O.V. Molchan, I.I. Smolich, O.G. Yakovets Plant physiology: laboratory practice for students of the Faculty of Biology. Minsk: BSU. 2011. 76p.

[20] A.E. Russkikh, S.G. Skugoreva. Influence of organic fertilizers on the content of photosynthetic pigments in lettuce leaves. Ecology of the native land: problems and ways to solve them: Materials of the XV All-Russian scientific and practical conference with international participation. Book. 2. Kirov: VyatSU. 2020. P.167-170. 